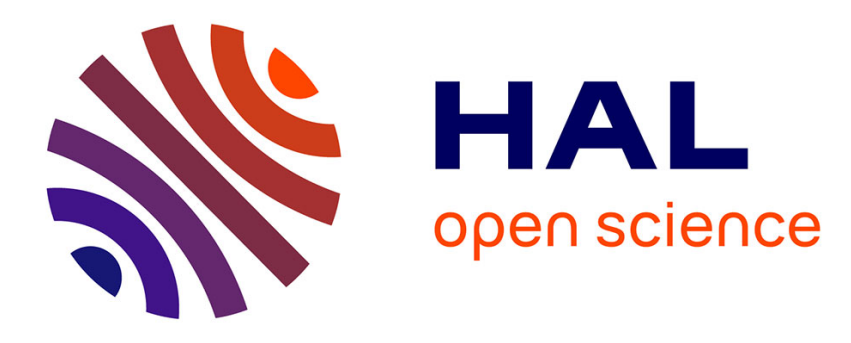

\title{
The Application of the Personalization Model in Diversity Management
}

Nurcan Karamolla Ensari, Norman Miller

\section{To cite this version:}

Nurcan Karamolla Ensari, Norman Miller. The Application of the Personalization Model in Diversity Management. Group Processes and Intergroup Relations, 2006, 9 (4), pp.589-607. 10.1177/1368430206067679 . hal-00571633

\section{HAL Id: hal-00571633 \\ https://hal.science/hal-00571633}

Submitted on 1 Mar 2011

HAL is a multi-disciplinary open access archive for the deposit and dissemination of scientific research documents, whether they are published or not. The documents may come from teaching and research institutions in France or abroad, or from public or private research centers.
L'archive ouverte pluridisciplinaire HAL, est destinée au dépôt et à la diffusion de documents scientifiques de niveau recherche, publiés ou non, émanant des établissements d'enseignement et de recherche français ou étrangers, des laboratoires publics ou privés. 


\title{
The Application of the Personalization Model in Diversity Management
}

\author{
Nurcan Karamolla Ensari \\ Alliant International University \\ Norman Miller \\ University of Southern California
}

\begin{abstract}
In an attempt to extend the existing approaches to diversity management, and present a theoretically based intervention strategy that offers ways to reduce prejudice at the workplace, this article reviews the Personalization Model (Brewer \& Miller, 1984; Ensari \& Miller, 2002; Miller, 2002) and its components (self-other comparison, self-disclosure, and empathy). We argue that, when applied in an organizational context, personalization can improve intergroup relations in organizations, and thereby increase effectiveness and productivity. The present article also discusses how personalization effects can be extended to the out-group as a whole, and proposes alternative ways to implement it in organizations. We further present ideas for future research that can potentially explore the beneficial effects of intergroup personalized contact at the workplace.
\end{abstract}

KEYWORDS diversity, intergroup relations, personalization

Is THERE still racial, ethnic, age, and gender discrimination in the US labor market? Reports show that African Americans are twice as likely to be unemployed and earn nearly $25 \%$ less when they are employed (Council of Economic Advisers, 1998). There is evidence that women and minorities often enter the organization at lower levels and hold lower level positions in organizations than do white males (Ragins, 1995). Gender discrimination contributed to the lack of career advancement in academic medicine (Carr, Szalacha, Barnett, Caswell, \& Inio, 2003), and in top management and executive positions (Powell, 1999). Prejudice and discrimination against minority people are part of the daily life in many organizations (e.g. the police force and health care), and negatively influence minority workers' performance, performance evaluation, and motivation (De Vries \& Pettigrew, 1998; Heilman, Martell, \& Simon, 1988; Morrison \& Von Glinow, 1990). Older workers are underrepresented in today's work force, partially due to employment practices that tend to favor the recruitment and retention of younger workers rather than older workers (Taylor \& Walker, 1997). A large percentage of

\section{Author's note}

Address correspondence to Nurcan Karamolla Ensari, Alliant International University, 1000 S. Fremont Ave., Alhambra, CA 91803, USA [email: nensari@alliant.edu] 
the employees that were interviewed agreed that stereotypes and prejudice exist in their departments (Cox \& Finley, 1995). Finally, research showed that experiences of discrimination at work have been associated with more negative relations with coworkers and supervisors, as well as with lower levels of job satisfaction and organizational commitment (Murrell, Olson, \& Hanson-Frieze, 1995).

Clearly, discrimination in the US labor market is evident, and it negatively impacts work life, creates work situations that disadvantage minorities, and poses major challenges for the future of organizations whose employees are becoming much more diverse. Although leaders and managers are aware of these negative consequences for their employees and organizations, they yet remain silent in most cases, and do not know what to do to correct such issues. In other cases, to proactively tackle discrimination, organizations engage in diversity management programs that are ineffective, being short-lived and brief in duration (Ponterotto, 1991), and often having the potential to produce negative outcomes (Riccucci, 1997; Rynes \& Rosen, 1995). Management and organizational psychology literature indicates that current diversity management initiatives and programs lack scientific rigor, empirical grounding, and theoretical scrutiny (Nkomo \& Cox, 1996). There is a clear lack of a theoretical-based, scientific intervention strategy that offers ways to reduce prejudice and discrimination in organizational settings. The present paper attempts to fill this gap by introducing the Personalization Model into diversity management and proposing possible ways to apply and implement this model in the workplace. Next, we describe the Personalization Model and its practical benefits, followed by ideas about how to utilize it in work settings. We conclude with directions for future research.

\section{The Personalization Model}

There are several social psychological models and interventions aimed at reducing intergroup conflict (see Ensari, 2002 for a review; Hewstone, 2000). Most of these models were derived from the contact hypothesis (Allport, 1954), which argued that positive and cooperative contact between members of previously hostile groups reduces prejudice. Allport (1954) believed that, as part of the development of personality, an individual must be able to relate him or herself warmly to others in both intimate and non-intimate contacts to achieve a fundamental acceptance of self and others. One of the main components of self-objectification is humor, which implies not only the ability to maintain positive relations with oneself and others, but also the ability to see incongruities connected to them (Allport, 1954). According to Allport (1954), beneficial intergroup contact must meet certain conditions. These include: (a) the establishment of cooperative and goaloriented contact under circumstances wherein there is equal status between members of the two groups; and (b) the creation of situations that allow for a personalized interaction and the provision of support by relevant social groups and authorities. Besides these conditions, there are many different aspects of contact that determine its consequences on attitudes (Allport, 1954). For example, the quantitative aspects of contact include frequency and duration; the role aspects of contact include both competitive and cooperative activity, as well as superordinate-subordinate role relations; and the social aspects include the presence or absence of a history of conflict and whether or not the contact is based on voluntary involvement (Allport, 1954). Some of these aspects directly influence the degree to which the positive attitudes that may evolve from contact will be extended toward the whole outgroup. That is, as the contact involves more outgroup members of equal status over a variety of cooperative situations, and as the social atmosphere surrounding the contact becomes more supportive, individuals in contact situations will more easily extend their positive attitudes and perceptions to the whole out-group category. When applied in an organizational setting, intergroup contact is expected to reduce the stress and performance pressures that typically are experienced more keenly by minority employees (Blau, 1977; Kanter, 1977), and 


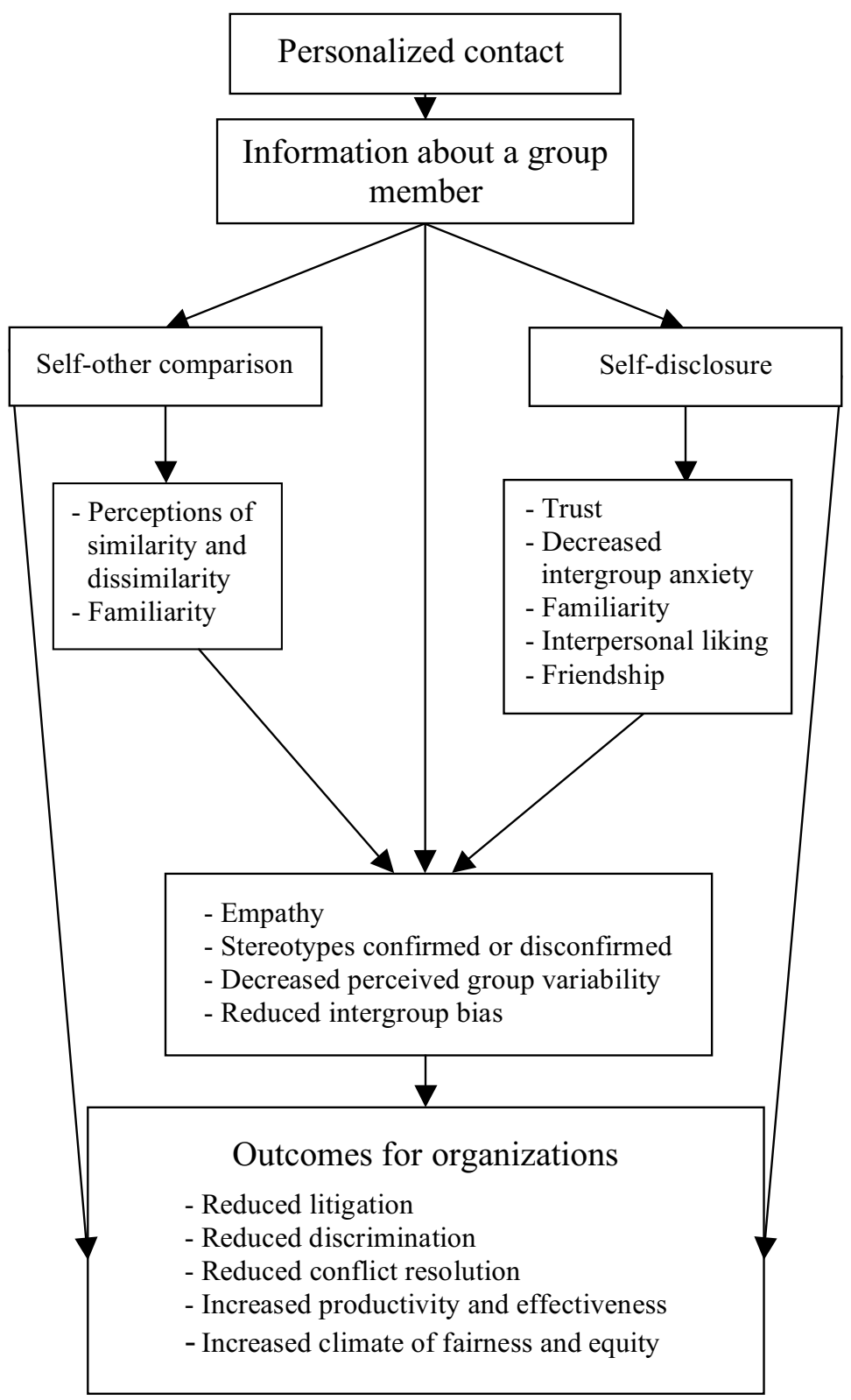

Figure 1. The personalization process.

provide channels for conflict resolution, thereby avoiding the accumulation of grievances, and the development of grudges (Newcomb, 1947).
Based on the contact hypothesis, the Personalization Model (previously called the Decategorization Model, Brewer \& Miller, 1984, 1988) suggests that contact between group 
members should be more personalized, thus allowing the development of perceptions which reflect the unique characteristics of out-group members and at the same time, generate feelings of familiarity between the members of the groups. There are several conceptually distinguishable components of personalized interaction. Specifically, these are: self-other comparison, self-disclosure, and perspective taking, including the sympathy or empathy that ensues from it. The following sections discuss these components.

\section{Self-other comparison}

Social comparison is ubiquitous, automatic, and intrinsic to social interaction. Self-other comparison allows out-group members who are in contact to note aspects of self and other that are similar or dissimilar (see Figure 1) (Brewer \& Miller, 1984; Miller, 2002). That is, during personalized interaction, information about an out-group member is compared to self. One notes dimensions on which another is similar or dissimilar to self, but in addition, one differentiates those who generally are more similar to self from those generally different. This latter process causes perceptions of group variability to be increased. During the process of self-other comparison, group members might become motivated to self-disclose personal information, as well as to step into each other's perspective to consider how things might look from the other side and thereby experience empathetic understanding (Batson et al., 1997; Galinsky \& Moskowitz, 2000; Miller, 2002). We discuss these latter processes next.

\section{Self-disclosure}

Self-disclosure is another component of personalized interaction. It refers to the sharing of personal, intimate information with othersinformation that they would not normally know or discover (Miller, 2002). Self-disclosure involves risk and creates vulnerability on the part of the person sharing the information. It thereby promotes trust, which in turn reduces the anxiety and discomfort implicit in intergroup encounters (Miller, 2002; Stephan \& Stephan, 1985). Self-disclosure also promotes familiarity and permits better processing of individual information (Rothbart \& John, 1985). Moreover, intimate information that is shared with someone else is valued more because it is more rarely discussed and thus less available than non-intimate information (Petty \& Mirels, 1981; Taylor, DeSoto, \& Lieb, 1979). Consequently, because self-disclosure to an outgroup member implies interpersonal attraction and liking, it reduces the negative bias that characterizes attitudes toward the out-group (e.g. Bettencourt, Brewer, Croak, \& Miller, 1992; Brewer \& Miller, 1984, 1988; Ensari \& Miller, 2002; Worchel, 1986).

Friendship is an important aspect of selfdisclosure (Cook, 1984; Pettigrew, 1971; Wilder, 1984). When intimate information is received and shared, it is perceived as more rewarding and valuable (Lynn, 1978; Petty \& Mirels, 1981), and implies being trusted by the discloser (Altman \& Haythorn, 1965; Fitzgerald, 1963). Such personal relationships create friendships, which lead to positive attitudes toward the out-group encounter, and eventually generalize to the group as a whole (Pettigrew, 1997). Students who had more out-group friends during their college years exhibited less out-group bias and intergroup anxiety at the end of college (Levin, van Laar, \& Sidanius, 2003). Further supporting the importance of friendship, Ensari and Miller (2002) showed that self-disclosure by an out-group member induces not only feelings of shared intimacy and trust, but also perceptions of friendliness. As a result, the combination of these subjective effects of intimacy, trust, and friendship mediated reduced prejudice toward new members of the out-group category.

In addition to direct contact with an outgroup member, indirect forms of contact can also have beneficial effects on intergroup attitudes. One type of indirect contact is a friendship between a fellow in-group member and an out-group member. In support of the importance of indirect friendship, the extended contact hypothesis argued that, 'mere knowledge that an in-group member (other than self) has a close relationship with an out-group member can lead to more positive intergroup attitudes' (Wright, Aron, 
McLaughlin-Volpe, \& Ropp, 1997, p. 74). Wright et al. (1997) argued that observing an in-group/out-group friendship should not evoke negative emotions such as anxiety, which ordinarily is associated with direct intergroup contact (Stephan \& Stephan, 1989). Thus, even though direct intergroup contact can be diminished due to intergroup anxiety and negative stereotypes, the extended contact hypothesis proposes a means by which widespread reductions in prejudice could occur without everyone having to have such direct out-group friendships (Wright et al., 1997).

\section{Empathy and perspective taking}

Empathy has been defined in a number of different ways. Some definitions emphasize an ability to cognitively understand another's internal state (e.g. Borke, 1971; Hogan, 1969; Underwood \& Moore, 1982). This emphasis has been termed perspective taking. Also frequent, however, is a definition that emphasizes affect, such as experiencing an emotion similar to that felt by another person (e.g. Eisenberg \& Miller, 1987; Feshbach \& Roe, 1968; Stotland, 1969) or, somewhat more broadly, as having an affective response that is congruent with another's welfare or emotional state (e.g. Batson et al., 1988; Mehrabian \& Epstein, 1972). In this latter view, empathy is synonymous with sympathy (Worchel, 1986).

Although the distinction between definitions that emphasize the cognitive versus the affective component of empathy may be important for some research arenas, what matters for our purposes herein is that in all definitions empathy is a vicarious reaction that occurs from witnessing another person's condition or emotional state. As such, its likelihood of occurrence is augmented after perceiving that another person has been harmed. In intergroup settings, a common characteristic is the dominance of one group over the other (in terms of power, status, access to desired resources, etc.). Implicit in the noting of such differences is the perception of relative harm or injustice. The awareness of such disparity sets the stage for perspective taking, which is why many remedial efforts at prejudice reduction include consciousness-raising elements. When the out-group member belongs to the more disadvantaged category, the opportunity for sympathy can become particularly salient. Thus, although empathic (sympathetic) anger and indignation is a common response after witnessing harm befall another in-group member (Davis, 1994), similar sympathetic reactions can be elicited by personalized contact with outgroup members.

Another key effect is that empathy increases helping behavior toward others. Substantial research in the helping literature demonstrates robust connections between empathy and helping (e.g. Aronfreed, 1970; Batson, 1991; Carlson \& Miller, 1987; Dovidio, Allen, \& Schroeder, 1990; Eisenberg \& Miller, 1987; Staub, 1978.) Such empathic responding is intensified when one has a close connection with, or identifies with, the person who has experienced the negative harm (Cialdini, Brown, Lewis, Luce \& Neuberg, 1997) The likelihood of such feelings of identification or connection can be increased by self-other comparison and by self-disclosure-two antecedent components of personalization that function to increase empathy (see Figure 1).

\section{Conclusion}

The Personalization Model has been supported in a series of experimental studies (e.g. Bettencourt et al., 1992; Cook, 1978; Ensari \& Miller, 2001, 2002, 2005; Harrington, 1988; MarcusNewhall, Miller, Holtz, \& Brewer, 1993; Miller, Brewer, \& Edwards, 1985; Wilder, 1978). Other support is seen in recent field studies of conflict in Northern Ireland (Brown \& Hewstone, 2005). Taken together, these studies show that personalized contact can disconfirm the negative stereotype of members of out-groups, diminished in-group/out-group distinctions, increased perceived variability among outgroup members, and thereby, reduce intergroup conflict. In contrast, depersonalized interaction, such as that which is more characteristic of many computer-mediated communication systems, promotes intergroup differentiation and attitude polarization (Postmes, Spears, \& Lea, 2002). When applied 
in an organizational context, personalized contact is expected to enhance employee effectiveness and interpersonal communication among employees, reduce litigation, and create a climate of fairness and equity. It should also provide channels for conflict resolution, and increase productivity on complex tasks, organizational effectiveness, and profit.

\section{Extension of the positive effects of personalization to the out-group as a whole}

The Personalization Model suggests that prejudice reduction should start by establishing positive interpersonal relationships between group members, while at the same time maintaining the salience of category identity cues if they are not manifestly salient. ${ }^{1}$ Of course, in many important instances, such salience routinely is manifestly high, as it is, for instance, with respect to gender differences, many racial/ethnic differences, age cohort differences, nationally distinct language groups, etc. A problem with the process of interpersonal contact is that when it occurs between individuals whose category identities are not identifiable, there is no reason to hope that significant improvements in that interpersonal relationship will lead to more extensive positive intergroup relations. Even when it occurs between individuals whose category identities are manifestly salient, as evidenced for instance by the dress code differences that characteristically distinguish management from blue collar workers, however, Haslam (2001) has argued that a perception of employees as individuals violates the social reality that conflict management strategies are designed to address. Specifically, he stated that: 'in the case of conflict between union and management, to suggest that negotiators treat each other as if they were individuals ... denies the real clash of group-based interests that make negotiation necessary in the first place' (Haslam, 2001, p. 188). Moreover, research on the interpersonal/intergroup discontinuity effect shows that bargainers who function as representatives of their respective groups behave even more competitively and antagonistically than either the groups themselves or than individual members of the respective groups (Insko \& Schopler, 1998).

Nevertheless, in order for the positive effects of a personalized contact with an out-group member to be extended to the out-group as a whole, category identities do need to remain salient in the contact setting, and group members must be seen as representatives of their categories. This argument is in line with Dovidio \& Gaertner's (1999) dual-identity model of conflict resolution, which asserts: (a) the salience of individual identity is necessary to ensure that the contact creates positive attitudes toward the out-group members, but at the same time; (b) the salience of group identity is necessary in order to associate these out-group members with their category and thereby allow the newly developed positive attitudes toward them to be extended to the group as a whole. Recently, Ensari and Miller (2001, 2005) provided evidence supporting the idea that the beneficial effects of personalized contact do become extended to other members of the outgroup category. They proposed that the interactive effects of personalization and category salience or typicality lead to a greater reduction in prejudice than personalization or salience (or typicality) alone. In a series of experiments wherein a typical or atypical out-group confederate self-disclosed either personal, or instead, impersonal information to the participant, they have confirmed the benefits of this approach. In these experiments, wherein the category identity of participants was not manifestly obvious from their physical appearance, category salience was experimentally induced to be salient by having the participants wear nametags displaying their group membership throughout the experiment. The results consistently showed that reduced prejudice toward new out-group members was greater when personalization co-occurred with high typicality or high salience of group membership, by comparison with conditions that examined their independent effects (Ensari \& Miller, 2001, 2005). 


\section{Conceptual differences between}

\section{personalization and decategorization}

Decategorization, or decategorized responding, refers to perceptions in which the salience of category distinctions is low (see Figure 2). There are at least four distinct means of inducing decategorization of an out-group.

First, one can provide information indicating the additional group categories to which outgroup members belong. On some of such category dimensions, the out-group person may hold in-group memberships that are shared with the perceiver. Thus, such additional information makes the target of evaluation appear more complex, which can diminish the effects of the original categorization (Crisp, Hewstone,
\& Rubin, 2001). Research within the crossed categorization paradigm addresses this approach (e.g. Crisp, Ensari, Hewstone, \& Miller, 2003; Crisp \& Hewstone, in press; Miller, Kenworthy, Canales, \& Stenstrom, in press; Miller, Urban, \& Vanman, 1998; Urban \& Miller, 1998).

When this first mode of decategorization occurs at the group, as opposed to the individual, level, subgrouping may occur-a process of 'organizing information into multiple clusters of individuals who are similar to one another in some way and different from other group members' (Maurer, Park, \& Rothbart, 1995, p. 813). When perceivers recognize distinctions between members of a certain category, they start

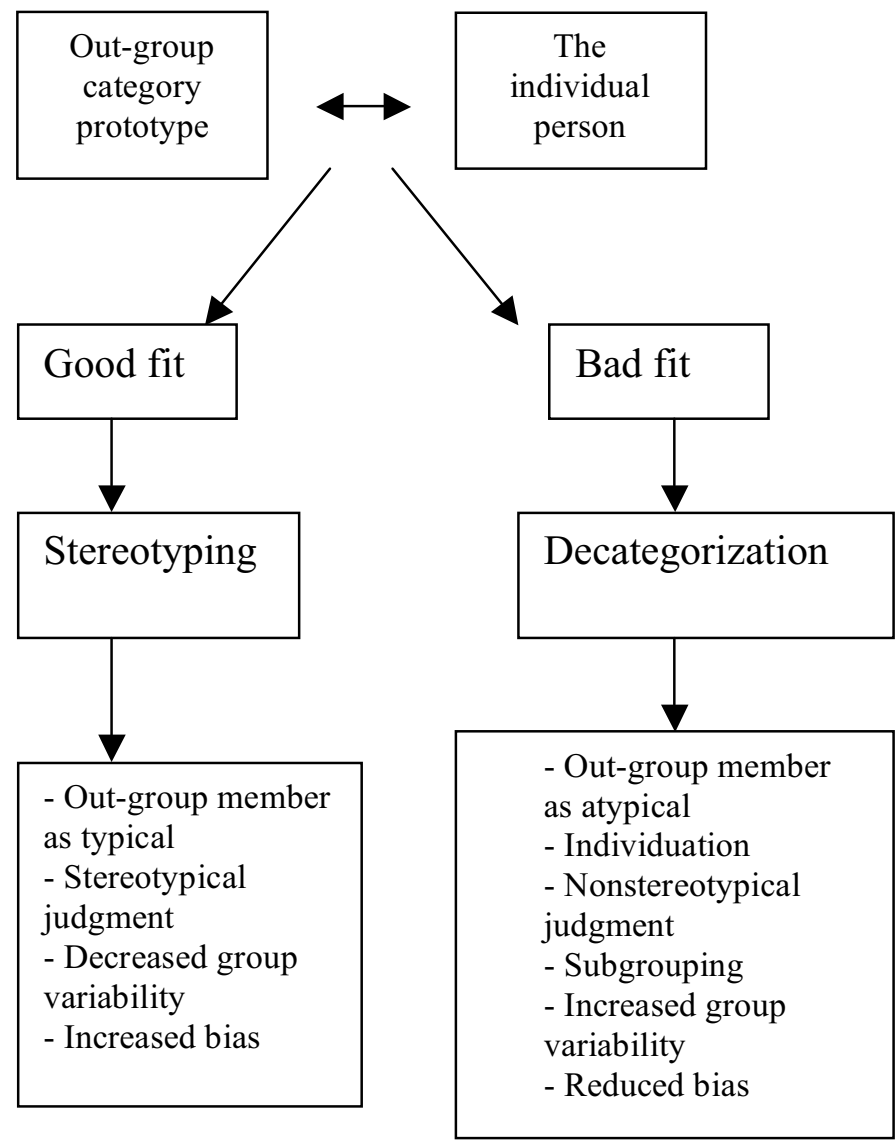

Figure 2. The decategorization process. 
creating subgroups within a larger superordinate category. Subgrouping can eventually increase the complexity of intergroup perceptions (i.e. perceived group variability), which is associated with reduced prejudice (Richards \& Hewstone, 2001).

A second approach is to make a superordinate category salient. Gaertner and Dovidio (2000) have developed a very substantial body of research that supports the efficacy of this approach. The out-group is recategorized into a broader in-group that includes the perceiver's category. Especially in times of external threat, the various subgroups that comprise a pluralistic society or a structurally differentiated business firm might put aside sources of realistic group conflict within the society or firm and rally to jointly support their superordinate identity, whether it be as Americans or as members of the XYZ company. To the degree that they do, the initial category distinction is eroded.

A third mode of inducing decategorization involves the presentation of additional counterstereotypical information about a particular out-group as a whole (Miller, 2002). Such information might aim to refute existing negative stereotypes by providing new information that dispels the substantive basis for them, or instead, promote a more positive image of the group by suggesting that it possess positive attributes not ordinarily associated with the category. Thus, decades ago the AntiDefamation League, an organization that sought to diffuse and reduce anti-Semitism, included in its remedial propaganda evidence that there was not a disproportionate number of Jews among bankers in the US, thereby hoping to dispel the stereotype that Jews exerted inordinate control of the banking industry. Taking the other tack, African American advocacy groups have promoted awareness of the Tusgegee Airmen, a squadron of African American pilots who served in the US Air Force during World War II. In response to such information, the perceiver might develop a more differentiated perception of such minority groups, but also, when the valence of that additional information is positive, it might in principle create a less negative perception of that out-group. In practice, however, this latter mode of inducing decategorization has not been shown to be effective in reducing bias towards out-group members (Locksley, Borgida, Brekke, \& Hepburn, 1980; Stratton, Canales, Armas, \& Miller, 2006).

Personalization is distinct from these topdown modes of decategorization (Brewer \& Miller, 1984). Personalization is a bottom-up process in which the information encoded about an out-group member during a social interaction is not dominated by the relevant social category, but rather, by the unique attributes of that individual. Impression formation begins mainly with recognizing and decoding the out-group category member, and proceeds linearly from the individual attributes to higher levels of comprehension. That is, personalization involves the piecemeal acquisition and integration of information that begins ' $a t$ the most concrete level and stops at the lowest level of abstraction required by the prevailing processing objectives' (Brewer, 1988, p. 6). Thus, the person will perceive the attributes of the out-group member, whether through self-disclosure by the target of perception or by information provided by a third party, and then process the new information by engaging in self-other comparison. Such processing may in turn elicit empathy. Consequently, personalization is expected to produce stronger and more impactful motivational and cognitive effects than decategorization and individuation per se, and thereby lead to less prejudicial judgments (Miller, 2002).

As argued, personalized interaction can not only reduce bias against the out-group member involved in the interaction (Berg \& WrightBuckley, 1988; Fiske \& Neuberg, 1990), but also, its benefits can extend to other members of the out-group, particularly when the outgroup member with whom such interaction has occurred is perceived as representative (i.e. is typical) of his/her social category (Brown \& Hewstone, 2005; Ensari \& Miller, 2001, 2005; Hewstone \& Brown, 1986; Hewstone \& Lord, 1998).

Finally, unlike the three top-down modes of 
decategorization discussed above, there is one mode of decategorization that is more akin to personalization in that it is a bottom-up process that does individuate a particular out-group member. In this mode of decategorization, an out-group member is differentiated from the prototype of the out-group. By providing information which shows that individual out-group members do not simplistically conform to their group stereotype, a more complex perception of that out-group is thereby induced. Presumably, such heightened complexity of perceptions of the out-group undercuts category-based responding. Nevertheless, Brewer's (1988) discussion sees this mode of decategorization as also being more top-down than bottom-up, primarily because category attributes are such a salient feature of the processing task. In Brewer's analysis, categorization of the individual occurs by noting a connection between the individual's characteristics and the prototype of that category that is held in memory. This prototype is accessed from long-term memory after having been triggered by a stimulus in the environment (Mischel, 1979). When there is a good fit between the target individual's characteristics and one's own abstract ideas about what category members are like, that individual is then categorized into the relevant category and seen as typical. On the other hand, when the individual fits the prototype poorly, $\mathrm{s} / \mathrm{he}$ is characterized as atypical, and differentiated from other category members.

As applied to members of an out-group, the result of such thought is that, to the degree that each individual is perceived as having attributes other than those that perfectly match the prototype, it induces one to begin to perceive those out-group members as unique individuals. Even though it is true that as a stimulus-person is categorized into the relevant category the activated category prototype causes observers to selectively attend to, encode, and retrieve schema-consistent information (Kenney, Blascovich, \& Shaver, 1994), nevertheless, differences between the individual and the prototype are noticed. To the degree that such individuation occurs, a decategorized perception has been induced and one has assessed each person on his/her own merits, not according to stereotypes. And as each out-group individual is assessed, differences among them will become apparent, thereby decategorizing that out-group.

A problem with this mode of decategorization, however, is that the more the target individuals are shown to differ from the out-group prototype on stereotype-defining dimensions, the greater the likelihood that those individuals will be subtyped as not truly belonging to the out-group. Consequently, there will be no basis for any positive perceptions based on the individuating information concerning the decategorized individual to be extended to other out-group members or to the out-group category as a whole.

\section{The application of the Personalization Model in organizations}

Unless proactive attempts are made to bring about contact, many people in organizations avoid it, are segregated by the organizational structure, or have no opportunity for contact.

The absence of contact is likely to reduce the likelihood of future contact, strengthen the assumption that the two groups have different (even irreconcilable) beliefs, maintain intergroup anxiety, and reinforce the boundary between groups. (Hewstone \& Greenland, 2000, p. 140)

Although the importance of applying the Personalization Model in organizations is evident, the question that remains for managers and employers is how to successfully implement it. Below, we consider alternative strategies for implementation of the Personalization Model at the workplace.

\section{Education}

One way to impart knowledge about and acquaintance with out-groups is direct teaching (Allport, 1954). Some past studies suggest that learning about an out-group improves attitudes and stereotypes (e.g. Gardiner, 1972). Knowledge of differences and similarities between the groups has a direct impact on prejudicial attitudes (Stephan \& Stephan, 1985). In fact, 
Allport and Kramer (1946) found that $71 \%$ of 400 college students who received information consisting of 'scientific facts about race' were less prejudiced than before. At the same time, however, proponents of realistic group conflict theory (e.g. LeVine \& Campbell, 1972) note that conflict, and ensuing bias and prejudice, is more likely among adjacent groups because they are in competition for the same scarce resources. At the same time, such adjacency and competition allows them to respectively develop rich, well-developed characterizations of one another. Consequently, groups often most strongly hate those whom they know most about (e.g. Israelis and Palestinians; the subgroups of the former state of Yugoslavia; the Rwandan conflict between Tutsi and Hutu; the oppressors and oppressed of Dacour; Greek and Turkish Cypriots, etc.). Moreover, as noted earlier, the presentation of positive information about a social category often fails to effectively reduce bias and prejudice (Locksley et al., 1980; Stratton et al., 2006).

This suggests to us that programs designed to present educational information per se about out-groups, often emphasizing their unique and distinctive customs and cultural attributes, will function to increase the salience of group differences. In turn, such salient distinctions can be pointed at to justify the prejudice that ensues from the realistic intergroup conflict that often exists within distinct units of an organization, such as, for instance that between production and sales. Instead, we suggest seminars, workshops, and lectures that educate employees about: (a) the social psychological bases of ethnocentrism and prejudice; and (b) the sociological and psychological reasons why different customs have developed in various ethnic groups to serve the same fundamental human needs. These educational programs can incorporate a personalization element by using the members of the respective groups to initiate such discussion by drawing on material from their own lives to emphasize the shared similarities that underlie their respective differencesthereby eliciting the benefits of self-disclosure and empathy.

The method and format of an education program depends on the audience, on time restrictions, and on particular circumstances affecting how it will be applied. In lecture format, the content is primarily informational and didactic, with factual outcomes and real-life examples (Arrendondo, 1995). An interactive format includes simulations, role playing, guided imagery, written activities, and other experiential exercises. In line with these arguments, however, educational methods involving more direct and personal experiences with other groups and group members, such as engaging in social trips or role-playing, providing an opportunity to learn about their lives, and increasing sympathy, are likely to have a more lasting effect (Allport, 1954; Smith, 1943).

Finally, it is important to reiterate that standalone educational programs that are implemented without other concurrent strategies will have a low impact in changing employee attitudes. Attitude change is a long-term process that cannot be achieved through brief education programs. Instead, it should be viewed as one ongoing initiative within a larger plan for organizational change.

\section{Creating and developing personalized contact at the workplace}

At the core of any attempt to create a personalized interaction among group members is to provide personal, individuating information about the out-group members. This information can directly be shared by the out-group employee (such as in a social setting), or instead, be introduced by a third party (such as a colleague). When employees learn something about each others' personal lives, they will have a chance not only to discover the similarities between them and self, but also to develop an understanding of the differences. New information about an out-group employee, when presented at the individual, as opposed to the category level, will enable them to better respect the customs and traditions of other groups, and to differentiate myths from realities. When personalized interaction develops among the group members, it should reveal stereotypedisconfirming, as well as stereotype-confirming, 
information to allow employees to break down the monolithic perception of out-group members. It should be noted that stereotypedisconfirming information alters stereotypes and reduces prejudice only if out-group behavior is associated with its category (as we discussed above), occurs often, and occurs in many situations (Rothbart \& John, 1985).

As mentioned, cross-group friendship is also very powerful in reducing prejudice (Cook, 1978; Pettigrew, 1998; Wright et al., 1997). Research found that organizations with a high number of external friendship links among organizational subunits are more effective in responding to crises than most organizations (Krackhardt \& Stern, 1988). However, the effective structure does not occur naturally, but must be designed consciously and carefully. Therefore, the managers and leaders of organizations should provide employees with the opportunity to become friends, not enemies or competitors, and to develop close interactions that make the aspects of personalization (self-other comparison and self-disclosure) possible. When there are severely limited choices to engage in interpersonal contact at work, such as in homogeneous work groups, little opportunity is available to employees for creating or becoming involved in personalized interaction or developing friendships. When such opportunities are available to group members, on the other hand, they not only create a forum for interpersonal conversations during which the out-group employees can bring out individualizing information about themselves, but also, they facilitate exchange of work information and conflict resolution. Exclusion of an outgroup member from such opportunities is likely not only to undercut his/her commitment and motivation, but also his/her performance.

Importantly, as indicated, simple contact alone is not sufficient to reduce discrimination (Pettigrew, 1998; Pettigrew \& Tropp, 2000) and can sometimes be a catalyst for escalating conflict (Hewstone \& Greenland, 2000). Thus, frequent personalized intergroup contact does not guarantee that relationships will always be positive and friendly. Generally, negative interactions have greater impact on attitudes, cognition, and behavior, and create more severe reactions than do positive or neutral events (see Labianca \& Brass, 1997; Taylor, 1991 for a review). It is often difficult to avoid negative interactions between the group members within an organization (e.g. disliking each other, or intention to disrupt other's outcomes), because of the required workflow interactions or hierarchical supervisory relationships (Labianca, Brass, \& Gray, 1998). Eventually, such episodes have the potential to reverse the beneficial effects of positive interpersonal contact, creating a more hostile work environment (Labianca et al., 1998).

One important barrier to obtaining optimal intergroup conditions in the workplace is the emotional expression that occurs during personalized contact. Anxiety, fear, and irritation often accompany intergroup contact, and can create negative reactions (Dijker, 1987; Gudykunst, 1993; Stephan \& Stephan, 1985, 1989). Thus, communication in heterogeneous groups is more formal, less frequent, and less effective than in homogeneous groups (Cox, 1993). In order to reduce these negative emotions, positive contact should continue over time, and occur over different situations and out-group members. Repeated exposure to an out-group and its members leads to liking (Zajonc, 1968), and thus makes intergroup encounters comfortable and 'right' (Pettigrew, 1998). When employees experience positive interpersonal relationships with different outgroup members in varied settings over a period of time, they will eventually change their attitudes toward them.

One way to develop personalized contact is to create cooperative interaction among the diverse employees at the workplace. This cooperative task should require collaborative efforts and interdependence in its execution, and provide a common goal to achieve (such as a reward for group success) (Cook, 1984). Crossfunctional teams can serve that purpose by bringing different work units to work on a common task together. For instance, when collaborating on a team with newcomers, employees with long tenure may provide information about the past organizational changes, 
crisis or merger, or avenues of access to upper levels of management, increasing upward communication in the organization (Jackson \& Joshi, 2004). Another way to create personalized contact at the workplace is to arrange meetings that are attended by employees from different work groups. These meetings create opportunities to understand differences and similarities between their work roles and how these roles contribute to the organizational mission, and increase cross-functional communication (Cox, 1993; Ensari, 2001).

Finally, both educational programs and strategies for implementing the personalization model require expertise for implementation. A facilitator or an instructor, from inside or outside the organization, should not only be an expert in issues concerning prejudice, but also be knowledgeable about organizational culture, affirmative action, and diversity management, and be able to use interdisciplinary approaches that bring social psychological models into the organization.

\section{Organizational support}

One of the important barriers that organizations should cope with is institutionalized discrimination (Allport, 1954; Pettigrew, 1986). Institutional norms structure the form and effects of contact situations (Kinloch, 1981; Pettigrew, 1998). Therefore explicit organizational sanction and interventions at the organization level are required in order for norms that support intergroup acceptance to be effectively developed, and the beneficial outcomes of personalized contact to prevail. Of course, it is crucial that top management provides its full support with a budget plan that allocates funds for the application of new initiatives. As indicated, however, this needs to be preceded by an analysis of the dysfunctional organizational structures that work to maintain and/or augment intergroup discord.

One way to signal organizational change is to recruit more minority employees not only at the low level positions, but also in the higher echelons as well (Allport, 1954). The new employees will eventually integrate into the organizational culture, and be tolerated and respected as soon as their merits as individuals become apparent (Allport, 1954). It is the management's responsibility to ensure that the new employees can retain their distinctive identities in a climate of tolerance, rather than to be forced to assimilate into the existing culture (Berry, 1984; Hewstone \& Brown, 1986).

\section{Directions for future research}

The literature on the effects of personalization at the workplace is very limited. No prior study has specifically examined the Personalization Model in an organizational setting. Laboratory studies have tested the contact hypothesis using work groups (Cook, 1969, 1971) and have examined the role of friendship among organizational subunits in crisis situations (Krackhardt \& Stern, 1988). A few field studies have examined the relationship between interpersonal relations and conflict in organizations (e.g. Labianca et al., 1998; Nelson, 1989). Very little empirical work, however, has examined intergroup personalized contact at the level of the entire organization. Most of these past experiments used students who simulate organizations, and types of management games and activities. This gap in the literature clearly limits our understanding of the practical applications of the Personalization Model in organizations.

Future research should aim to fill in this gap by conducting laboratory experiments on the effects of personalization on prejudice with real and artificial work groups, and follow up with field and longitudinal studies conducted in organizations. Such a laboratory experiment can follow, for example, Cook's (1969, 1971) experimental paradigm, which used a cooperative task (a type of a management game) that required interdependence and a common goal with out-group team members. The key feature of such an experiment is to impose a personalization manipulation, such as self-other comparison, self-disclosure, and/or empathy after having implemented a cooperative task. Obvious extensions of such research not only include examination of different types (selfother comparison versus self-disclosure), but also different levels (e.g. from knowing names to 
sharing intimate information) of personalized contact, as well as the role of frequency of personalization (quantitative) and the quality of personalization on intergroup bias in organizations.

A separate concern is that the focus of previous social psychological experiments on personalization and contact has exclusively addressed the reduction of intergroup bias, ignoring the effectiveness of the teamwork (Brewer, 1995). Therefore, it is also important to examine how bias and team effectiveness correlate in such experiments.

Another idea for laboratory research is to examine the effects of personalization in combination with those of crossed categorizations. As Brewer (1995) argued, categorical distinctions involve organizational role distinctions (e.g. marketing and human resources departments) as well as demographic differences among work group members (e.g. race and gender). When functional divisions converge (e.g. marketing managers work with human resource staff), the in-group/out-group distinctions between these respective workgroups, as well as the social category distinctions within each, can create problematic implications for their respective effectiveness (e.g. conflict, distrust, anxiety, etc.) (Brewer, 1995). In the laboratory, when circumstances do not arouse anxiety about competent task performance, such crossing of role functions with social category distinctions can reduce bias (MarcusNewhall et al., 1993). When personalized interaction is combined with the crossing of categories, can it reduce bias even in the face of anxiety about task competence? Little research addresses such issues.

Another consideration for future research is the valence of the information disclosed during personalized contact. Although positive information is more common in day-to-day interactions than negative information (Altman \& Taylor, 1973), past research produced conflicting results with respect to the effects of negative and positive disclosure in interpersonal relations. Some argued that positive disclosure elicits higher levels of intimacy than negative disclosure (Taylor \& Belgrave, 1986). Consist- ently, it was found that negative disclosure leads to less liking than positive disclosure, and that negative disclosers are viewed as less competent and more threatening than positive disclosers (Dalto, Ajzen, \& Kaplan, 1979; Lazarus \& Averill, 1972). Past research suggested that perceivers may often come to dislike individuals who characterize themselves using their negative experiences and attributes (Lazowski \& Andersen, 1990). On the other hand, some studies found that negative self-disclosure increased liking (Jones \& Archer, 1976), and was perceived as more intimate than positive disclosure (Howell \& Conway, 1990). Because the communication of negative information about the self is less common than the reporting of ego-enhancing events in day-to-day interactions, it may seem more relevant and informative to listeners (Altman \& Taylor, 1973). One possible problem with these studies, however, is that it was not clear if the discloser was liked more because high intimate disclosers elicit greater reciprocity than low intimate disclosers (Taylor \& Belgrave, 1986), or because the information revealed was negative. That is, it is likely that the effect of valence was confounded with the level of intimacy in these past studies. Therefore, future studies that address the issue of valence and intimacy level will extend our understanding of the effects of these variables on intergroup bias.

Examination of possible mediating and moderating factors of personalization is also important for future research. Reduced prejudice toward new members of the out-group category is mediated by perceptions of the out-group member as typical, as friendly, and as disclosing information that is personal and unique (Ensari \& Miller, 2002). Typicality was also found to be a moderator such that personalization was more beneficial under conditions of high typicality (Ensari \& Miller, 2002). That is, when an out-group member disclosed intimate information about herself, attitudes toward other out-group members became more favorable when that out-group member was presented as a typical one. Making internal ability attributions for the out-group member's success is another significant mediator (Ensari \& Miller, 
2005). Additionally, past research suggested that group identification can play an important role as a mediator and as a moderator. Whereas identification with a minority group mediated the effects of perceived discrimination on selfesteem (Schmitt, Spears, \& Branscombe, 2003), it can also serve as a moderator in different contexts (e.g. Postmes, Spears, \& Lee, 2005; Postmes, Spears, Sakhel, \& de Groot, 2001). In sum, future research should focus on other potential mediators, and moderators (such as status relationship and group size) and explore the circumstances under which the Personalization Model can most be effective in reducing prejudice in organizations.

As previously indicated, educational interventions and programs aimed at reducing prejudice can increase knowledge, understanding, and awareness through provision of general and specific (personalized) information. Evaluating their effectiveness is another direction for future research. Although the design and implementation of such empirical evaluation is difficult (Rossi \& Freeman, 1993), it is important to determine the long-term impact of such interventions on knowledge, and stereotypes, attitudes, and behavioral change.

\section{Conclusion}

This article specifically focused on the Personalization Model and its benefits in reducing prejudice in organizations. Throughout our discussion, however, we have discussed several other approaches and interventions that proposed ways to reduce prejudice, such as Mutual Intergroup Differentiation (Hewstone \& Brown, 1986), Stereotype-Disconfirming Information (Rothbart \& John, 1985), Crosscategorization (Deschamps \& Doise, 1978), and Common In-group Identity (Gaertner \& Dovidio, 1993). This array of models suggests that there are many possibilities of creating a more peaceful work environment. Although each of these models offers a different approach to intergroup conflict reduction, organizations must realize that prejudice and discrimination are more likely to be reduced by a gradual and integrative involvement of each one of these interventions, and a multilevel approach.
If we accept that there are different types of change to achieve, and that different interventions may realize different types of change, then our future interventions will need to be more complex to be more successful. (Hewstone, 2000, p. 397)

Finally, even after the Personalization Model is applied and the prejudice is reduced at the workplace, improvements in attitudes toward the out-group members might be limited across situations and individuals, inhibiting generalization across situations, from the out-group individual to the out-group, and from the immediate out-group to other out-groups (Pettigrew, 1998). To achieve generalization, repeated optimal personalized contact should occur among the typical group members, and when the category information is salient in the environment (Ensari \& Miller, 2002; Rothbart \& John, 1985; Van Oudenhoven, Groenewoud, \& Hewstone, 1996). When the potential for extensive and repeated contact in a variety of social contexts is available in organizations, employees are more likely to generalize their positive attitudes to others.

\section{Note}

1. The personalization model (Brewer \& Miller, 1984) was initially presented in a book concerned with school desegregation. At the time, research on school desegregation was almost entirely constrained to the study of Black/White relations, wherein the relevant category memberships are invariably highly salient as a result of the uniquely distinctive physical appearance cues of each respective group. Because the model was presented in this context (i.e. as one of an array of chapters concerning Black/White relations) category salience was never explicitly stated to be a necessary component of the model. Instead, we merely assumed that it would be necessarily high. Our implicit recognition of the importance of category salience, however, was evidenced in the operationalizations we employed when experimental tests of the model were based on the construction of arbitrary groups. Routinely, members of each artificial group (e.g. dot overestimators and dot underestimators) were made to wear distinctively colored sweatshirts with the respective names of each group across 
the front (e.g. Bettencourt et al., 1992;

Harrington, 1988; Marcus-Newhall et al., 1993; Miller et al., 1985) thereby mimicking the high salience of category distinctiveness that typically exists in Black/White confrontations. Thus, category salience was assumed to be a component of the model despite the absence of an explicit statement to that effect.

\section{References}

Allport, G. W. (1954). The nature of prejudice. Reading, MA: Addison-Wesley.

Allport, G. W., \& Kramer, B. M. (1946). Some roots of prejudice. Journal of Personality and Social Psychology, 22, 9-39.

Altman, I., \& Haythorn, W. W. (1965). Interpersonal exchange in isolation. Sociometry, 28, 411-426.

Altman, I., \& Taylor, D. A. (1973). Social penetration: The development of interpersonal relationships. New York: Holt, Rinehart and Winston.

Aronfreed, J. (1970). The socialization of altruistic and sympathetic behavior: Some theoretical and experimental analyses. In J. Macaluay \& L. Berkowitz (Eds.), Altruism and helping behavior. New York: Academic Press.

Arrendondo, P. (1995). Successful diversity management initiatives: A blueprint for planning and implementation. Thousand Oaks, CA: Sage.

Batson, C. D. (1991). The altruism question: Toward a social psychological answer. Hillsdale, NJ: Erlbaum.

Batson, C. D., Dyck, J. L., Brandt, J. R., Batson, J. G., Powell, A. L., McMaster, M. R., \& Griffitt, C. (1988). Five studies testing two new egoistic alternatives to the empathy-altruism hypothesis. Journal of Personality and Social Psychology, 55, 52-77.

Batson, C. D., Sager, K., Garst, E., Kang, M., Rubchinsky, K., \& Dawson, K. (1997). Is empathy-induced helping due to self-other merging? Journal of Personality and Social Psychology, 73, 495-509.

Berg, J. H., \& Wright-Buckley, C. (1988). Effects of racial similarity and interviewer intimacy in a peer counseling analogue. Journal of Counseling Psychology, 35, 377-384.

Berry, J. W. (1984). Cultural relations in plural societies: Alternatives to segregation and their sociopsychological implications. In N. Miller \& M. B. Brewer (Eds.), Group in contact: The psychology of desegregation (pp. 11-27). Orlando, FL: Academic Press.

Bettencourt, B. A., Brewer, M. B., Croak, M. R., \& Miller, N. (1992). Cooperation and reduction of intergroup bias: The role of reward structure and social orientation. Journal of Experimental Social Psychology, 28, 301-319.

Blau, T. H. (1977). APA Commission on Accelerating Black Participation in Psychology. American Psychologist, 25, 1103-1104.

Borke, H. (1971). Interpersonal perception of young children: Egocentrism or empathy? Developmental Psychology, 5, 263-269.

Brewer, M. B. (1988). A dual process model of impression formation. In Srull, T. K. \& Wyer, R. S. Jr. (Eds.), A dual process model of impression formation (pp. 1-36). Hillsdale, NJ, England: Lawrence Erlbaum Associates, Inc.

Brewer, M. B. (1995). Managing diversity: The role of social identities. In S. E. Jackson \& M. N. Ruderman (Eds.), Diversity in work teams: Research paradigms for a changing workplace (pp. 47-68). Washington, DC: American Psychological Association.

Brewer, M. B., \& Miller, N. (1984). Beyond the contact hypothesis: Theoretical perspectives on desegregation. In N. Miller \& M. B. Brewer (Eds.), Group in contact: The psychology of desegregation (pp. 281-302). Orlando, FL: Academic Press. Brewer, M. B., \& Miller, N. (1988). Contact and cooperation: When do they work? In P. Katz \& D. Taylor (Eds.), Eliminating racism: Means and controversies (pp. 315-326). New York: Plenum.

Brown, R., \& Hewstone, M. (2005). An integrative theory of intergroup contact. In M. P. Zanna (Ed.), Advances in experimental social psychology (pp. 255-343). San Diego, CA: Elsevier Academic Press.

Carlson, J., \& Miller, N. (1987). Explanation of the relation between negative mood and helping. Psychological Bulletin, 102, 91-108.

Carr, P. L., Szalacha, L., Barnett, R., Caswell, C., \& Inio, T. (2003). A 'ton of feathers': Gender discrimination in academic medical careers and how to manage it. Journal of Women's Health, 12, 1009-1018.

Cialdini, R. B., Brown, S., Lewis, B. P., Luce, C., \& Neuberg, S. L. (1997). Reinterpreting the empathy-altruism relationship: When one into one equals oneness. Journal of Personality and Social Psychology, 73, 481-494.

Cook, S. W. (1969). Motives in a conceptual analysis of attitude-related behavior. In W. J. Arnold \& D. Levine (Eds.), Nebraska Symposium on motivation (pp. 179-235). Lincoln, NE: University of Nebraska Press.

Cook, S. W. (1971). The effect of unintended interracial contact upon racial interaction and attitude change 
(Final report, Project No. 5-1320). Washington, DC: US Department of Health, Education and Welfare, Office of Education.

Cook, S. W. (1978). Interpersonal and attitudinal outcomes in cooperating interracial groups. Journal of Research and Development in Education, 12, 97-113.

Cook, S. W. (1984). Cooperative interaction in multiethnic contexts. In N. Miller \& M. B. Brewer (Eds.), Group in contact: The psychology of desegregation (pp. 155-185). Orlando, FL: Academic Press.

Council of Economic Advisers (1998). Changing America: Indicators of Social and Economic Well-Being by Race and Hispanic Origin. Washington, D.C.: U.S. Government Printing Office.

Cox, T. H., Jr. (1993). Cultural diversity in organizations. San Fransisco: Berrett-Koehler.

Cox, T. H., Jr., \& Finley, J. A. (1995). An analysis of work specialization and organization level as dimensions of workforce diversity. In M. M. Chemers \& S. Oskamp (Eds.), Diversity in organizations: New perspectives for a changing workplace (pp. 62-88). Thousand Oaks, CA: Sage.

Crisp, R. J., Ensari, N., Hewstone, M., \& Miller, N. (2003). A dual-route model of crossed categorization effects. In W. Stroebe \& M. Hewstone (Eds.), European review of social psychology (pp. 35-73). Philadelphia: Psychology Press.

Crisp, R. J., \& Hewstone, M. (in press). Multiple social categorization: Processes, models, and applications. Philadelphia: Psychology Press.

Crisp, R. J., Hewstone, M., \& Rubin, M. (2001). Does multiple categorization reduce intergroup bias? Personality and Social Psychology Bulletin, 27, 76-89.

Dalto, C. A., Ajzen, I., \& Kaplan, K. J. (1979). Self-disclosure and attraction: Effects of intimacy and desirability on beliefs and attitudes. Journal of Research in Psychology, 13, 127-138.

Davis, M. H. (1994). Empathy: A social psychological approach. Boulder, CO, US: Westview Press.

De Vries, S., \& Pettigrew, T. F. (1998). Effects of ethnic diversity: The position of minority workers in two Dutch organizations. Journal of Applied Social Psychology, 28, 1503-1530.

Deschamps, J. C., \& Doise, W. (1978). Crossed category memberships in intergroup relations. In H. Tajfel (Ed.), European review of social psychology (pp. 263-292). Chichester, UK: Wiley.

Dijker, A. J. (1987). Emotional reactions to ethnic minorities. European Journal of Social Psychology, 17, 305-325.

Dovidio, J. F., Allen, J. L., \& Schroeder, D. F. (1990).
Specificity of empathy-induced helping: Evidence for altruistic motivation. Journal of Personality and Social Psychology, 59, 249-260.

Dovidio, J., \& Gaertner, S. L. (1993). Stereotypes and evaluative intergroup bias. In D. M. Mackie \& D. L. Hamilton (Eds.), Affect, cognition, and stereotyping: Interactive processes in group perception (pp. 167-193). San Diego, CA, US: Academic Press, Inc.

Dovidio, J., \& Gaertner, S. L. (1999). Reducing prejudice: Combating intergroup biases. Current Directions in Psychological Science, 8, 101-105.

Eisenberg, N., \& Miller. P. A. (1987). The relation of empathy to prosocial and related behaviors. Psychological Bulletin, 101, 91-119.

Ensari, N. (2001). How can managers reduce intergroup conflict at a workplace? Social-psychological approach to prejudice in organizations. The Psychologist-Manager Journal, 5, 83-93.

Ensari, N. (2002). The role of leaders and consultants in fostering international organizations. In R. Lowman (Ed.), Handbook of organizational consulting psychology: A comprehensive guide to theory, skills, and techniques, (pp. 493-515). Jossey-Bass.

Ensari, N., \& Miller, N. (2001). Decategorization and the reduction of bias in the crossed categorization paradigm. European Journal of Social Psychology, 31, 193-216.

Ensari, N., \& Miller, N. (2002). Out-group must not be so bad after all: The effects of disclosure, typicality and salience on intergroup bias. Journal of Personality and Social Psychology, 83, 313-329.

Ensari, N., \& Miller, N. (2005). Prejudice and intergroup attributions: The role of personalization and performance feedback. Group Processes EO Intergroup Relations, 8, 391-410.

Feshbach, N. D., \& Roe, K. (1968). Empathy in six and seven year olds. Child Development, 39, 133-145.

Fiske, S. T., \& Neuberg, S. L. (1990). A continuum of impression formation, from category-based to individuation processes: Influences of information and motivation on attention and interpretation. In M. P. Zanna (Ed.), Advances in experimental social psychology (pp. 1-74). New York: Academic Press.

Fitzgerald, M. P. (1963). Self-disclosure and expressed self-esteem, social distance, and areas of the self revealed. Journal of Psychology: Interdisciplinary $\mathcal{E}^{2}$ Applied, 56, 405-412.

Gaertner, S. L., \& Dovidio, J. F. (2000). Reducing intergroup bias: The common ingroup identity model. Philadelphia, PA: Psychology Press. 
Galinsky, A. D., \& Moskowitz, G. B. (2000). Perspective-taking: Decreasing stereotype expression, stereotype accessibility, and in-group favoritism. Journal of Personality and Social Psychology, 78, 708-724.

Gardiner, G. S. (1972) Complexity training and prejudice reduction. Journal of Applied Social Psychology, 2, 326-342.

Gudykunst, W. B. (1993). Toward a theory of effective interpersonal and intergroup communication: An anxiety/uncertainty management (AUM) perspective. In R. L. Wiseman \& J. Koester (Eds.), Intercultural communication competence (pp. 33-71). Thousand Oaks, CA: Sage.

Harrington, H. J. (1988). The effects of personal contact on intergroup relations. Unpublished dissertation, University of Southern California, Los Angeles.

Haslam, S. A. (2001). Psychology in organizations: The social identity approach. London: Sage.

Heilman, M. E., Martell, R. F., \& Simon, M. C. (1988). The vagaries of sex bias: Conditions regulating the undervaluation, equivaluation, and overvaluation of female job applicants. Organizational Behavior and Human Decision Processes, 41, 98-110.

Hewstone, M. (2000). Contact and categorization: Social psychological interventions to change intergroup relations. In C. Stangor (Ed.), Stereotypes and prejudice: Essential readings (pp. 394-418). New York: Psychology Press.

Hewstone, M., \& Brown, R. J. (1986). Contact is not enough: An intergroup perspective on the 'contact hypothesis'. In M. Hewstone \& R. J. Brown (Eds.), Contact and conflict in intergroup encounters (pp. 1-44). Oxford, UK: Blackwell.

Hewstone, M., \& Greenland, K. (2000). Intergroup conflict. International Journal of Psychology, 35, 136-144.

Hewstone, M., \& Lord, C. G. (1998). Changing intergroup cognitions and intergroup behavior: The role of typicality. In C. Sedikides, J. Schopler, \& C. Insko (Eds.), Intergroup cognition and intergroup behavior (pp. 367- 392). Hillsdale, NJ: Erlbaum.

Hogan, R. (1969). Development of an empathy scale. Journal of Consulting and Clinical Psychology, 33, 307-316.

Howell, A., \& Conway, M. (1990). Perceived intimacy of expressed emotion. Journal of Social Psychology, 130, 467-476.

Insko, C. A., \& Schopler, J. (1998). Differential distrust of groups and individuals. In C. Sedikides $\&$ J. Schopler (Eds.), Intergroup cognition and intergroup behavior (pp. 75-107). Mahwah, NJ: Erlbaum.

Jackson, S. E., \& Joshi, A. (2004). Diversity in social context: A multi-attribute, multilevel analysis of team diversity and sales performance. Journal of Organizational Behavior, 25, 675-702.

Jones, E. E., \& Archer, R. L. (1976). Are there special effects of personalistic self-disclosure? Journal of Experimental Social Psychology, 12, 180-193.

Kanter, R. (1977). Men and women of the organization. New York: Basic Books.

Kenney, R. A., Blascovich, J., \& Shaver, P. R. (1994). Implicit leadership theories: Prototypes for new leaders. Basic and Applied Social Psychology, 15, 409-437.

Kinloch, G. C. (1981). Ideology and contemporary sociological theory. Englewood Cliffs, NJ:

Prentice-Hall.

Krackhardt, D., \& Stern, R. N. (1988). Informal networks and organizational crises: An experimental simulation. Social Psychology Quarterly, 51, 123-140.

Labianca, G., \& Brass, D. J. (1997). Exploring the social ledger: The role of negative affective relationships in social networks. Best papers proceedings, 57th annual conference of the Academy of Management, Boston, MA.

Labianca, G., Brass, D. J., \& Gray, B. (1998). Social networks and perceptions of intergroup conflict: The role of negative relationships and third parties. Academy of Management Journal, 41, 55-67.

Lazarus, R. S., \& Averill, J. R. (1972). Emotion and cognition with special reference to anxiety. In C. D. Sielberger (Ed.), Anxiety: Current trends in theory and research (pp. 242-283). New York: Academic Press.

Lazowski, L. E., \& Andersen, S. M. (1990). Self-disclosure and social perception: The impact of private, negative, and extreme communications. Journal of Social Behavior and Personality, 5, 131-154.

Levin, S., van Laar, C., \& Sidanius, J. (2003). The effects of ingroup and outgroup friendships on ethnic attitudes in college: A longitudinal study. Group Processes E Intergroup Relations, 6, 76-92.

LeVine, R. A., \& Campbell, D. T. (1972). Ethnocentrism: Theories of conflict, ethnic attitudes and group behavior. New York: Wiley.

Locksley, A., Borgida, E., Brekke, N., \& Hepburn, C. (1980). Sex stereotypes and social judgment. Journal of Personality and Social Psychology, 39, 821-831.

Lynn, S. J. (1978). Three theories of self-disclosure exchange. Journal of Experimental Social Psychology, 14, 466-479. 
Marcus-Newhall, A., Miller, N., Holtz, R., \& Brewer, M. B. (1993). Cross-cutting category membership with role assignment: A means of reducing intergroup bias. British Journal of Social Psychology, 32, 125-146.

Maurer, K. L., Park, B., \& Rothbart, M. (1995). Subtyping versus subgrouping processes in stereotype representation. Journal of Personality and Social Psychology, 69, 812-824.

Mehrabian, A., \& Epstein, N. (1972). A measure of emotional empathy. Journal of Personality, 40, 525-543.

Miller, N. (2002). Personalization and the promise of contact theory. Journal of Social Issues, 58, 387-410.

Miller, N., Brewer, M. B., \& Edwards, K. (1985). Cooperative interaction in desegregated settings: A laboratory analogue. Journal of Social Issues, 41, 63-79.

Miller, N., Kenworthy, J. B., Canales, C., \& Stenstrom, D. (in press). Explaining the effects of crossed categorization on ethnocentric bias. In R. J. Crisp \& M. Hewstone (Eds.), Multiple social categorization: Processes, models, and applications. Philadelphia: Psychology Press.

Miller, N., Urban, L. M., \& Vanman, E. J. (1998). A theoretical analysis of crossed categorization effects. In C. Sedikedes, J. Schopler, \& C.A. Insko (Eds.), Intergroup cognition and intergroup behavior (pp. 393-422). Hillsdale, NJ: Erlbaum.

Mischel, W. (1979). On the interface of cognition and personality: Beyond the person-situation debate. American Psychologist, 34, 740-754.

Morrison, A. M., \& Von Glinow, M. A. (1990). Women and minorities in management. American Psychologist, 45, 200-208.

Murrell, A. J., Olson, J. E., \& Hanson-Frieze, I. (1995). Sexual harassment and gender discrimination: A longitudinal study of women managers. Journal of Social Issues, 51, 139-149.

Nelson, R. E. (1989). The strength of strong ties: Social networks and intergroup conflict in organizations. Academy of Management Journal, 32, 377-401.

Newcomb, T. M. (1947). Autistic hostility and social reality. Human Relations, 1, 69-86.

Nkomo, S. M., \& Cox, T., Jr. (1996). Diverse identities in organizations. In S. R. Clegg, C. Hardy, \& W. R. Nord (Eds.), Handbook of organization studies (pp. 338-356). London: Sage.

Pettigrew, T. F. (1971). Racially separate or together? New York, NY: McGraw Hill.

Pettigrew, T. F. (1986). The intergroup contact hypothesis reconsidered. In M. Hewstone \&
R. Brown (Eds.), Contact and conflict in intergroup encounters. Oxford, UK: Basil Blackwell.

Pettigrew, T. F. (1997). Generalized intergroup contact effects on prejudice. Personality and Social Psychology Bulletin, 23, 173-185.

Pettigrew, T. F. (1998). Intergroup contact theory. Annual Review of Psychology, 49, 65-85.

Pettigrew, T. F., \& Tropp, L. R. (2000). Does intergroup contact reduce prejudice? Recent meta-analytic findings. In S. Oskamp (Ed.), Reducing prejudice and discrimination. (pp. 93-114). Mahwah, NJ: Lawrence Erlbaum.

Petty, R. E., \& Mirels, H. L. (1981). Intimacy and scarcity of self-disclosure: Effects on interspersonal attraction for males and females. Personality and Social Psychology Bulletin, 7, 493-503.

Ponterotto, J. G. (1991). The nature of prejudice revisited: Implications for counseling intervention. Journal of Counseling and Development, 70, 216-224.

Postmes, T., Spears, R., \& Lea, M. (2002). Intergroup differentiation in computer-mediated communication: Effects of depersonalization. Group Dynamics, 6, 3-16.

Postmes, T., Spears, R., Sakhel, K., \& De Groot, D. (2001). Social influence in computer-mediated communication: The effects of anonymity on group behavior. Personality and Social Psychology Bulletin, 27, 1243-1254.

Postmes, T., Spears, R., \& Lee, A. T. (2005). Individuality and social influence in groups: Inductive and deductive routes to group identity. Journal of Personality and Social Psychology, 89, 747-763.

Powell, G. N. (1999). Handbook of gender and work. Thousand Oaks, CA: Sage.

Ragins, B. R. (1995). Diversity, power, and mentorship in organizations: A cultural, structural, and behavioral perspective. In M. Chemers, S. Oskamp, \& M. A. Costanzo (Eds.), Diversity in organizations: New perspectives for a changing workplace (pp. 91-132). Thousand Oaks, CA, US: Sage Publications, Inc.

Riccucci, N. M. (1997). Cultural diversity programs to prepare for work force 2000: What's gone wrong? Public Personnel Management, 26, 10-23.

Richards, Z., \& Hewstone, M. (2001). Subtyping and subgrouping: Processes for the prevention and promotion of stereotype change. Personality and Social Psychology Review, 5, 52-73.

Rossi, P. H., \& Freeman, H. E. (1993). Evaluation: A systematic approach. Thousand Oaks, CA: Sage.

Rothbart, M., \& John, O. P. (1985). Social categorization and behavioral episodes: A 
cognitive analysis of the effects of intergroup contact. Journal of Social Issues, 41, 81-104.

Rynes, S., \& Rosen, B. (1995). A field survey of factors affecting the adoption and perceived success of diversity training. Personnel Psychology, 48, 247-270.

Schmitt, M. T., Spears, R., \& Branscombe, N. R. (2003). Constructing a minority group identity out of shared rejection: the case of international students. European Journal of Social Psychology, 33, $1-12$.

Smith, M. E. (1943). A comparison of judgment of prejudice toward certain racio-national groups before and since the entry of the United States into World War II. Journal of Social Psychology, 18, 393-400.

Staub, E. (1978). Positive social behavior and morality: I. Social and personal influences. Oxford, UK: Academic Press.

Stephan, W. G., \& Stephan, C. W. (1985). Intergroup anxiety. Journal of Social Issues, 41, 157-175.

Stephan, W. G., \& Stephan, C. W. (1989). Antecedents of intergroup anxiety in Asian-Americans and Hispanic-Americans. International Journal of Intercultural Relations, 13, 203-219.

Stotland, E. (1969). Exploratory investigations in empathy. In L. Berkowitz (Ed.), Advances in experimental social psychology (pp. 271-314). New York: Academic Press.

Stratton, J., Canales, C., Armas, V., \& Miller, N. (2006). Positive stereotyping. Manuscript submitted for publication.

Taylor, S. E. (1991). Asymmetrical effects of positive and negative events: The mobilizationminimization hypothesis. Psychological Bulletin, 110, 67-85.

Taylor, D. A., \& Belgrave, F. Z. (1986). The effects of perceived intimacy and valence on self-disclosure reciprocity. Personality and Social Psychology Bulletin, 12, 247-255.

Taylor, R. B., DeSoto, C. B., \& Lieb, R. (1979). Sharing secrets: Disclosure and discretion in dyads and triads. Journal of Personality and Social Psychology, 37, 1196-1203.

Taylor, P., \& Walker, A. (1997). Age discrimination and public policy. Personnel Review, 26, 307-318.

Underwood, B., \& Moore, B. (1982). Perspective-taking and altruism. Psychological Bulletin, 91, 143-173.
Urban, L. M., \& Miller, N. (1998). A theoretical analysis of crossed categorization effects: A meta-analysis. Journal of Personality and Social Psychology, 74, 894-908.

Van Oudenhoven, J. P., Groenewoud, J. T., \& Hewstone, M. (1996). Co-operation, ethnic salience, and generalization of interethnic attitudes. European Journal of Social Psychology, 26, 649-662.

Wilder, D. A. (1978). Reduction of intergroup discrimination through individuation of the outgroup. Journal of Personality and Social Psychology, 74, 961-967.

Wilder, D. A. (1984). Predictions of belief homogeneity and similarity following social categorization. British Journal of Social Psychology, 13, 323-333.

Worchel, S. (1986). The role of cooperation in reducing intergroup conflict. In S. Worchel \& W. Austin (Eds.), Psychology of intergroup relations (pp. 288-304). Chicago: Nelson-Hall.

Wright, S. C., Aron, A., McLaughlin-Volpe, T., \& Ropp, R. (1997). The extended contact effect: Knowledge of cross-group friendships and prejudice. Journal of Personality and Social Psychology, 73, 73-90.

Zajonc, R. B. (1968). Attitudinal effects of mere exposure. Journal of Personality and Social Psychology, 9.

Paper received 11 May 2005; revised version accepted 30 March 2006.

\section{Biographical notes}

NURCAN KARAMOLLA ENSARI is an associate professor at the Marshall Goldsmith School of Management at Alliant International University. She received her $\mathrm{PhD}$ at the University of Southern California, and completed postdoctoral work at the Kravis Leadership Institute, Claremont McKenna College. Her primary research interests are in intergroup relations, leadership, and diversity management.

NORMAn MILLER is the Silberberg Professor of Psychology at the University of Southern California. His research focuses on: intergroup relations; aggression; and social projection. 